\title{
Vozes da Independência
}

\author{
Rita de Cássia Marques Líma de Castro(t)
}

Resumo: Este artigo se propõe a abordar a independência da América Latina pela comparação de ideias de Simón Bolívar e José Martí, mentores e/ou executores de ideais que sustentaram o sonho da região livre e cujos escritos trazem, além dos argumentos em prol da liberdade, uma proposta política que, após mais de dois séculos, ainda reverbera nas vozes atuais. Realizar a compilação de algumas obras e apresentá-las sob uma ótica comparativa, por meio de pesquisa bibliográfica e análise de escritos, apresenta-se como uma oportunidade de analisar a independência da América Latina em suas estruturas primárias: ideias que levam à ação, atemporalmente.

Palavras-chave: Independência; América Latina; Pensamento Político; Bolívar; José Martí.

Abstract: This work aims at analyzing the Latin America independence through the ideals of Simón Bolívar and José Martí, mentors and/or executioners of ideas that supported the dream of a free region and whose writings, besides being in favor of liberty, represents a political proposal that after two centuries are echoed in today's voices. Compiling some works and presenting them with a comparison, by means of literature and analysis of writings, is regarded by us as an opportunity to analyze the Latin America independence process in its primary structure: the ideals that lead to action, timelessly.

Key-words: Independence; Latin America; Political Thought; Bolívar; José Martí.

(*) Estudante de Doutorado pelo Programa de Pós-Graduação em Integração da América Latina da Universidade de São Paulo - PROLAM/USP. Professora auxiliar de ensino no Insper e professora na UMC - Universidade de Mogi das Cruzes - Campus Villa-Lobos. E-mail: <ritalimadecastro@usp.br >; <ritalimadecastro@gmail.com>. Recebido em 21.9.2010 e aceito em 28.4.2011. 


\section{INTRODUÇÃO}

Para se debater os ideais dos homens que pensaram e agiram na América Latina, cabe compreender sua formação e o contexto da época em que viveram, o final do século XVIII e início do século XIX, período das independências das colônias latino-americanas. Assim, este artigo está dividido em duas seções: na primeira parte, apresentamos uma contextualização da época em que estouraram as revoluções que levaram à independência das nações latino-americanas, visando trazer a visão geral do que ocorria naquele momento histórico e quais as causas comuns das ações de independência.

Na segunda seção, inicialmente, são apresentadas breves biografias de Simón Bolívar e José Martí, escolhidos como representantes dessa categoria de homens pensadores-atores. Esses homens de ideia-ação, justamente por serem atores, não podem ser dissociados dos fatos, para que possamos compreender suas ideias políticas. Portanto, vale ressaltar, também contextualizamos regionalmente o espaço em que o pensador revolucionário exerceu suas ideias de nacionalidade, de maneira que possa haver melhor compreensão dos escritos, como defende Sociano (1977).

Lynch (2001) observa que a América, vasto continente de ideias particulares segundo as peculiaridades de cada sociedade distinta, desenvolvia uma consciência dessa nacionalidade bebendo de literatura exclusivamente americana, literatura esta inicialmente produzida pelos jesuítas. Posteriormente, ainda que houvesse a influência da filosofia francesa e das ideias do iluminismo, maior influência coube ao novo americanismo, como veremos no decorrer deste artigo.

A seguir, comparamos escritos selecionados de Simón Bolívar e José Martí, sendo que foram utilizados, para esta comparação, as versões em Língua Portuguesa e os textos em Espanhol, obtidos eletronicamente em bibliotecas virtuais, por considerarmos estes últimos a fonte mais precisa para a compreensão da ideia original, reduzindo-se o viés natural da versão para outro idioma. Nas ilustrações mais longas, optamos por deixar o texto escolhido em notas de rodapé, visando não quebrar o raciocínio comparativo.

Cabe ressaltar que a proposição de analisar comparativamente os escritos nos permite apresentar as ideias expostas, categorizando-as em temas, como apresentado adiante. É importante observar que todo recorte pressupõe escolhas e limitações; assim, esta comparação não tem a pretensão de ser exaustiva; apenas de apontar as ideias que consideramos mais pertinentes para o escopo deste trabalho.

\section{Contextualização — a América Latina pré-Independência}

Bomfim, em 1903, ao discorrer sobre os males de origem que fizeram a América Latina estagnar-se, males estes derivados do parasitismo que Espanha e Portugal exerceram sobre suas colônias, aponta os vícios decorrentes de 300 anos desse parasitismo, vícios estes que, por serem também um reforço às revoluções, valem ser aqui destacados: a exploração da terra sem a visão da conservação, sem a visão da "coisa pública"; um Estado visto apenas como opressor e tirânico e espoliador, uma população dividida, a formação de sociedades 
desabituadas ao trabalho, afeiçoadas a combates e aventuras guerreiras. "Perversão do senso moral, horror ao trabalho livre e à vida pacífica, ódio ao governo, desconfiança das autoridades, desenvolvimento de instintos agressivos." (BOMFIM, edição de 1993, p. 151.)

Esses vícios permaneceram após a independência e, ousamos afirmar que estão tão presentes hoje em dia como estavam quando Manoel Bomfim escreveu sua obra, no início do século XX. López Chirico (2008) aborda esses vícios denominando-os herança colonial e comenta que tal legado, além de ser um dos fatores da fragmentação das colônias em mais de vinte nações, também foram "a base das dificuldades para a conformação dos Estados nacionais até meados do século XIX” (LÓPEZ CHIRICO, 2008, p. 27). Como ponto positivo, no entanto, serviram como fator de união das nações emergentes em sua busca da independência, foram um fator comum entre elas.

Para Sodré (1997), a independência dos países latino-americanos, ainda que tenha sido particular em cada área colonial da Espanha e de Portugal, foi um processo único no que se refere ao conjunto de fatores que o impulsionaram. Esse processo tem início com a Revolução Industrial, passagem do mercantilismo para o capitalismo. O capitalismo traz a ascensão de uma nova classe — os burgueses e as exigências de abertura comercial e eliminação do trabalho escravos, exigências incompatíveis com o sistema colonial. Se quanto ao primeiro senão - a abertura comercial - houve associação de interesses entre a classe dominante nas colônias e a burguesia industrial europeia, quanto à abolição não houve consenso.

"A independência ocorre no momento em que as pressões externas pela liberdade de comércio, pela abertura do mercado colonial americano, conjugam-se com as pressões internas, no sentido de abolir a subordinação ao intermediário nas trocas." (SODRÉ, 1997, p. 142.) Esta visão assemelha-se à de John Lynch, entre outros historiadores. Ele defende que a ideia de ruptura deriva das reformas chamadas bourbônicas, cujo auge foi entre 1759-1788, época do reinado de Carlos III. Essas reformas foram muito centralizadoras e levaram os diferentes grupos sociais que compunham as colônias a reagirem com animosidade a esse controle, ampliando a difusão das ideias e sentimentos americanistas que explodem com a destituição do rei espanhol por Napoleão Bonaparte em 1808. Outros historiadores, como Tulio Donghi, associam diretamente as ações de independência das colônias a essa invasão francesa e à perda do poder espanhol (Soares, 2008).

Em 1808, quando a Espanha é invadida pela França e Napoleão destitui o rei, Fernando VII, José Bonaparte, irmão de Napoleão, passa a governar o país. As colônias espanholas na América se insurgem contra o governo local, não reconhecendo a autoridade, visto que não havia rei legítimo a quem respeitar, e formam juntas locais para governar, uma tradição medieval que trazia por trás a ideia de um governo legítimo, em que a vontade popular pudesse ser respeitada (López Chirico, 2008).

Segundo López Chirico (2008), o processo de independência da América Latina, embora tenha ocorrido de forma simultânea, não foi linear e tampouco houve profusão de contatos entre os movimentos revolucionários:

O Vice-Reinado da Nova Espanha (México) conseguiu sua independência isolado da América do Sul, ainda que com relações estreitas com a América Central influindo 
muito em seu processo. E na América do Sul, diferentes focos revolucionários autônomos - Caracas, Nova Granada (Colômbia), Chile, Rio da Prata — só chegaram a relacionar suas trajetórias porque a habilidade militar de Bolívar e San Martín percebeu que somente seria possível derrotar a Espanha fazendo com que todas as forças revolucionárias convergissem para o Peru, onde os espanhóis haviam se fortificado. Esta foi a razão das grandes campanhas de libertação continental que culminaram em Ayacucho, em 1824. (LÓPEZ CHIRICO, 2008, p. 34.)

Tal processo também sofreu uma alteração em seu objetivo: “(...) mudou de uma intenção meramente autonomista para a concepção de independência total.” (LÓPEZ CHIRICO, 2008, p. 33.) Mudança esta que não era uma unanimidade entre as populações de cada região e, portanto, muitas guerras civis se seguiram à independência. $O$ sonho de uma América unificada territorialmente ruiu, com exceção do Brasil, que conservou sua extensão territorial e teve um processo de independência mais caracterizado por emancipação do que por revolução. "No Brasil, o processo de emancipação importou mais na medida em que destruiu invertera das peias, que lhe embargavam o passo, do que pela introdução de práticas vigorosamente revolucionárias" (BARRETO et al., 1993, p. 39.)

No Brasil, ainda que a independência não tenha resultado em uma mudança de governo, visto que aqui se manteve a monarquia, não foi diferente a herança colonial e o processo de emancipação sofreu os mesmos entraves e resistências: “(...) as duas aspirações — a da independência e a da unidade — não nascem juntas e, por longo tempo ainda, não caminham de mãos dadas." (BARRETO et al., 1993, p. 9.)

Essas resistências são causadas, no dizer de Bomfim (ed. de 1993), pelos remanescentes da metrópole, aventureiros, parasitas e subparasitas que viviam da exploração e benesses da metrópole sobre a colônia e que ficaram na América Latina como um "dente de ixode", o dente que o parasita deixa, incomodando, quando larga a presa. Esses remanescentes, em um primeiro momento, resistiram à independência, mas quando constataram que esta era irreversível, acomodaram-se e ficaram incomodando a evolução política dessas nações latino-americanas, por meio da deturpação da razão primeira da revolução, intervindo e escamoteando, influenciando a ponto de, como apresentado na segunda seção, abalar algumas proposições como a da América unida, defendida por Bolívar, ou mesmo - e principalmente — reduzir as mudanças, manter o status quo.

Podemos afirmar que os processos de libertação das metrópoles aconteceram na América Latina, mas as mudanças estruturais, as que visavam mais justiça, igualdade e democracia, não vieram (López Chirico, 2008). Para Bomfim (ed. 1993), ao contrário dos Estados Unidos, nação que estava pronta quando afirmou sua independência, na América Latina tudo estava por fazer: “(...) não se tratava, apenas, de educar populações novas para a justiça e a liberdade; tratava-se também de combater, vencer e anular todos os vícios herdados do regime anterior, todas as poderosas influências retardatárias, abusos e maus hábitos." (BOMFIM, ed. 1993, p. 286.) Para López Chirico (2008), em se tratando da independência das colônias:

A consequência mais visível foi a ascensão das elites criollas aos postos que as cúpulas peninsulares tinham ocupado na colônia. Também, o triunfo da grande fazenda e dos senhores de terra que tenderam a prevalecer sobre as elites urbanas. E o progresso 
dos comerciantes nativos, agora em contato direto com a grande potência hegemônica mundial, a Inglaterra, com cujos emissários mais empreendedores deviam dividir o poder nos centros locais de comércio. (LÓPEZ CHIRICO, 2008, p. 48.)

\section{OS PENSADORES-ATORES DA INDEPENDÊNCIA}

\section{Bolívar - UM HOMEM “À MEDIDA IDEOLÓgICA do SEU TEMPo” (SOCIANO, 1977, P. 12)}

A República só poderia ser realizada e produzir bons resultados, quando dirigida e guiada pelos que a querem como indispensável para a conquista de um ideal superior — pelos republicanos de fé. (Manoel Bomfim. A América Latina - Males de Origem, p. 279)

José Antonio de la Santísima Trinidad Simón Bolívar y Palacios (1783-1830) foi um dos principais representantes de uma geração que lutou para que a América Latina pudesse se expressar como ela mesma, à parte das metrópoles que dominavam a região. Considerado um líder fundamental na emancipação das colônias espanholas da América do Sul, Bolívar defendeu um projeto de independência que atendia aos desejos e ao mesmo tempo era alimentado por várias forças políticas e sociais que estavam presentes na Capitania Geral da Venezuela e em outras colônias da América Latina (Sociano, 1977; López Cirico, 2008, Soares, 2008).

Filho de uma rica família de mantuanos (criollos, descendentes de espanhóis nascidos nas colônias), Bolívar cedo perdeu seus pais e aos nove anos passou a ser educado por Miguel José Sanz, advogado famoso na época, Andrés Bello (futuro reitor da Universidade do Chile) e Simón Carreño Rodríguez, iluminista, seguidor de Rousseau e considerado o primeiro influenciador de Bolívar com relação aos ideais de liberdade que fervilhavam tanto na América Latina quanto na Europa. Como era comum entre a classe mais rica das colônias, Bolívar completou seus estudos na Europa, mais precisamente na Espanha e na França. Lá, participou do fervilhar intelectual na Corte Espanhola e presenciou, in loco, a coroação de Napoleão Bonaparte, fato que, segundo alguns biógrafos, influenciou negativamente a visão da monarquia e reforçou em Bolívar os ideais republicanos (Soares, 2008; Sociano, 1977).

No final do século XVIII, Caracas era uma região tranquila, com uma sociedade composta por 30 a 40 mil habitantes, não muito cindida por não haver grande disparidade entre ricos e pobres, de maioria criolla (18 mil), mais escravos ( 7 a $14 \mathrm{mil})$ e brancos $(10 \mathrm{mil})$. Também como característica da época, a estratificação social seguia as Leis das Índias os brancos advindos da Espanha eram os que exerciam os altos cargos, depois se seguiam os brancos nascidos nas colônias (criollos), a quem, em geral, era dada a guarda dos cabildos (conselhos municipais que regulavam a vida dos habitantes das colônias e fiscalizavam as propriedades públicas), fora do governo central (Sociano, 1977; López Chirico, 2008).

Em 1807, após passar quatro anos na Europa, Bolívar retorna à Venezuela e dedica-se por dois anos aos seus negócios. Em 1809, é nomeado juiz - Magistrado Maior de Yade. Em 1810, o cabildo de Caracas desacata as ordens do capitão-geral da localidade e forma uma Junta, que passa a governar em nome do rei espanhol que estava cativo. Bolívar e Andrés Bello são enviados a Londres, para solicitar apoio econômico. 
Em Londres, Bolívar entra em contato com Francisco de Miranda, venezuelano revolucionário que já havia tentado a insurreição por duas vezes, desde 1806 e, em 1811, com o apoio de Bolívar, conduz a independência que duraria apenas um ano, por causa de dissensões políticas internas e uma estrutura de República que propunha o federalismo em uma região "quebrada" internamente, bem como o triunvirato como sistema de governo. Ambas as proposições eram "pouco adequadas para consolidar o nascimento e a existência política de um país cuja integração estava ainda muito longe de ser efetiva" (SOCIANO, 1977, p. 23).

Dessa lição, Bolívar escreve, em 1812, Manifiesto de Cartagena (ou Memória dirigida aos cidadãos da Nova Granada por um Caraquenho). Quando de seu exílio em 1815, escreve duas missivas: Carta de Jamaica, documento que contém os fundamentos jurídicos do movimento de independência, retrata a visão de Bolívar sobre o futuro político da América após sua independência e aponta como o mundo deveria se interessar pela causa da liberdade da América-colônia. O segundo documento, endereçado ao editor da Gazeta Real da Jamaica, procura argumentar que a causa da América é uma só, independentemente das raças (Sociano, 1977; Soares, 2008). Na Carta de Jamaica, no dizer de Sociano (1977), Bolívar:

Apresenta um quadro geral da América do tempo, assim como a intuição - com base nos conhecimentos que Bolívar possuía da sociedade e da vida política do Novo Mundo - do destino futuro dos países que nela nasceriam, com um tal acerto que a carta em questão foi baptizada com o nome de «carta profética». (SOCIANO, 1977, p. 27.)

De 1816 a 1819, há mudanças na condução do processo, desde a composição do exército, unificação do movimento em torno de Bolívar, até a alteração nos objetivos estratégicos da revolução. Em 1819, Bolívar pronuncia um discurso em Angostura, momento em que apresenta seu primeiro projeto de Constituição (Discursos de Angostura), o qual irá se completar em 1826 (Discurso al Congreso Constituyente de Bolivia) (SOCIANO, 1977). Com relação ao discurso proferido em 1819, comenta Sociano (1977):

Surge aqui um Bolívar mais maduro, consciente da necessidade de lançar as bases da existência política do país sobre pressupostos ideológicos diferentes dos de 1811, nos quais é possível encontrar claramente os resultados de sua formação clássica e das leituras de Montesquieu, Rousseau e Bentham, não obstante sem aderir cegamente às ideias expostas por estes pensadores, mas antes assimilando-as na intenção de buscar a melhor via para o convívio político num país cuja heterogeneidade social, cultural e geográfica não desconhece. Nesse projecto pronuncia-se pela divisão dos poderes em número de quatro, juntando aos três clássicos um «poder moral», necessário a um povo que aspira a ser virtuoso, clara manifestação da sua preocupação pelos defeitos do meio (que tenta neutralizar através da instituição do dito poder), da sua formação clássica (percebe-se o eco dos éforos e dos censores) e da possível influência da exaltação da «virtude» característica dos revolucionários franceses. (SOCIANO, 1977, p. 29-30.)

Bolívar procurou envolver a todos na luta pela independência da América, visto que seu projeto era fundado no princípio da igualdade entre os cidadãos. Utilizando-se de sua experiência nas tentativas frustradas de independência, Bolívar atraiu as camadas populares, mas não afastou a elite, dando um atendimento diferenciado aos seus oficiais comandantes. 
"Aos escravos, Bolívar acenou com a perspectiva da libertação; aos pardos, com a de distribuição de terras; aos índios, com o fim dos tributos especiais." (SOARES, 2008, p. 26.) Aos generais, Bolívar procurava estruturar a lealdade e afirmar sua autoridade.

Ademais de sua atuação procurando envolver os vários atores que poderiam ser como foram - causa de rachas internos que prejudicaram a unidade, Bolívar também buscava atuar na unificação política entre essas nações que estavam se constituindo. Para a segurança da América em si, Bolívar propunha uma política externa que levasse em conta as relações mútuas entre as nações ex-colônias da América Espanhola, relações que tomassem por base a independência da cada país e sua atuação conjunta em defesa contra o estrangeiro. Podemos encontrar, aqui, a "consciência de solidariedade continental" (SOCIANO, 1977, p. 42) que possuía Simón Bolívar.

De igual modo, outro ponto de destaque em Bolívar é sua compreensão da realidade imediata e dos impactos futuros que a falta de unidade poderia causar nas nações americanas. Bolívar via os Estados Unidos e a Inglaterra como nações potencialmente perigosas à soberania das recém-formadas repúblicas; bem como alertava para a questão de como as grandes potências europeias viam o hemisfério sul. Postulava, para tanto, que a América deveria ter um grande exército para defendê-la, que houvesse um congresso de todos os Estados americanos e que ocorresse o desenvolvimento de políticas externas para manter relações com Estados Unidos, Inglaterra e demais potências europeias que preservassem a autonomia e a unidade das nações americanas (texto desenvolvido com base em Sociano, 1977).

Bolívar, ademais de sua visão avançada, foi um homem de ação, um general que participou ativamente dos movimentos de independência, conquistando desde a independência da Venezuela, em 1819, até o Alto Peru, em 1825. No entanto, apesar da conquista da liberdade, o sonho da pátria única e grande não se concretizou e as dissensões internas fizeram com que essas nações fossem se separando do projeto inicial de unificação da Grã-Colômbia (que envolvia o que hoje são Colômbia, Equador, Panamá e Venezuela). Aos poucos, venezuelanos e equatorianos romperam com a unificação e constituíram seus próprios governos. A última tentativa de Bolívar visando à unificação foi a Constituição da Bolívia, escrita em 1826, mas que resultou infrutífera quanto ao sonho de uma América única.

A Bolívar restou a renúncia à presidência, em 1830, ano em que falece, desiludido e doente. No entanto, sua visão de emancipação e de desenvolvimento de relações mais duradouras entre as nações da América latina perdura até os dias atuais. Recentemente, o presidente da Venezuela declarou que sua revolução social era bolivariana, assim como a nova Constituição desenvolvida (SOARES, 2008, p. 37).

Homem do seu tempo, quis transformar ao mesmo tempo as forças sociais e as instituições, sem se aperceber de que estas resultam vazias se não forem sustentadas e impulsionadas por aquelas. O destino de Bolívar estava, portanto, condicionado pela necessidade histórica de ter de fazer muito em muito pouco tempo. Destruíra uma ordem tri-secular, mas era impossível que pudesse instaurar uma nova em três anos. (...) Os projetos de Bolívar foram, não obstante, o maior esforço que se fez para tentar pôr a América espanhola à altura dos tempos (...) crendo efetiva e firmemente na possibilidade de encontrar uma via que assegurasse a estabilidade de instituições 
que conduzissem realmente à solução dos problemas que afligiam o Novo Mundo. (SOCIANO, 1977, p. 49-50.)

\section{José Martí — o homem da descoberta e CONQUista do TEMPO REAL do CONTINENTE}

O homem precisa crer na excelência da obra a que se propõe e a que se dedica, precisa confiar na vantagem e na eficácia dos seus esforços. (Manoel Bomfim. A América Latina - males de origem, 1993, p. 279.)

José Julián Martí y Perez (1853-1895) é considerado herói nacional em Cuba, mentor da revolução cubana ocorrida no século XX, um pensador latino-americano que inspira, até hoje, ideais de liberdade. Assim como Bolívar, Martí foi um pensador atuante do processo de independência de seu país e um escritor que compreendeu a América Latina como um continente. "Martí foi o primeiro a compreender que não se tratava tanto de pôr em dia quanto de descobrir, e simultaneamente conquistar, o tempo real do continente: sua situação concreta." (RETAMAR, 1983, p. 59.) Ao contrário de Bolívar, José Martí era de uma classe sem muitos recursos. Filho de imigrantes espanhóis humildes, logo cedo Martí teve de ajudar o pai em tarefas que procuravam suprir a família (oito filhos, sendo sete meninas) nos momentos de desemprego do progenitor (Villaça, 2008).

A Cuba de seu tempo era a penúltima colônia que ainda estava sob domínio espanhol (ver linha do tempo) e mostrava, desde o início do século XIX, grande modernização em sua produção de açúcar. Maior ilha do Caribe, Cuba tornou-se o principal exportador de açúcar do Caribe, após a revolução e independência do Haiti, e a modernidade em sua economia contrastava com o controle colonial, havendo muitos desejos de liberdade pairando no ar.

Nesse ambiente de inquietação, Martí viveu sua infância e adolescência. A primeira guerra da independência em Cuba ocorreu quando José Martí, 15 anos, estava na Escola Superior Municipal de Rapazes. Conhecida como a Revolução de Yara, essa guerra contra a Espanha durou dez anos e foi seguida da Guerra Chiquita (1879-1880) e, finalmente, da Guerra Chica (1895-1898), cujo final Martí não pôde ver, pois faleceu justamente no início dessa Guerra Chica, que resultou na independência de Cuba (Villaça, 2008; Retamar, 1983). Tendo participado ativamente da primeira e da terceira guerras, José Martí:

[...] teve um papel muito importante em todo esse processo histórico. A lucidez com que tratou a questão da dominação espanhola e denunciou a política expansionista norte-americana, bem como a beleza com que apresentou, por meio de ricas metáforas, seus sonhos de independência para toda a América, tornaram contagiantes seus escritos de época. (VILLAÇA, 2008, p. 11-12.)

Martí teve contato logo cedo com o criollo Rafael Maria de Mendive (1821-1886), diretor e professor de escola, patriota convicto que, ao conhecer Martí e identificar seu potencial, obteve autorização de seu pai e passou a custear os estudos do jovem José Martí. Até 1869, ano de seu desterro de Cuba, Mendive foi como um "segundo pai" para Martí e grande influenciador de seu pensamento (Retamar, 1983; Villaça, 2008).

Ao estourar a Guerra de Yara, Martí escreve sonetos apoiando a independência e ajuda a publicar um semanário democrata que não passa do primeiro número — La Patria 
Libre, publicando nele o famoso poema Abdala, no qual apresenta a história de um jovem (Abdala) que morre pela independência de sua pátria (Núbia = Cuba), tal qual ocorreu com Martí. O colégio de Mendive é fechado, Mendive é deportado e Martí é preso por subversão, sendo condenado a seis anos de prisão (Retamar, 1983; Villaça, 2008).

Dois anos após sua prisão, em 1871, a família consegue um indulto e a pena de prisão com trabalhos forçados é substituída por deportação para a Espanha, onde Martí fica até 1874 . Lá, encontra-se com outros deportados, como o amigo Valdés Dominguez e continua seus estudos em Madri e Zaragoza. Em um ambiente muito efervescente culturalmente e agitado politicamente, Martí conclui sua universidade e escreve dois textos impactantes: um sobre o presídio político em Cuba, no qual denuncia as torturas e as crueldades lá praticadas e, posteriormente, publica um ensaio polêmico, La Revolución Española ante la Revolución Cubana, em que acusa a Espanha de negar à Cuba e demais colônias os ideais de liberdade e valores republicanos que pregava.

Ao sair da Espanha, Martí conhece outros países como França, México, Guatemala, Venezuela e Estados Unidos. Nessas viagens, amadurece seu pensamento com relação à realidade da América Latina e passa a valorizar cada vez mais a educação como ponto importante para a formação das pessoas. Escreveu La Edad de Oro, obra com informações sobre história, geografia e economia da América Latina, voltada para a formação de crianças e jovens; funda, em 1890, a Liga da Instrução, escola em que procurava formar quadros políticos; defende a educação popular que permitisse a integração dos pobres na sociedade (Versos Sencillos é sua obra mais famosa a respeito). Continua atuando como professor, como assistente em um escritório de advocacia e como jornalista, defendendo suas convicções revolucionárias (Retamar, 1983; Villaça, 2008).

Em suas viagens às repúblicas latino-americanas, "abre-se à compreensão de uma unidade maior que ele chamará 'Nossa América', na qual Cuba aparece articulada” (RETAMAR, 1983, p. 18). Nos Estados Unidos, identifica as virtudes e os vícios do capitalismo desenvolvido, vivendo a fase em que a nação norte-americana transita do capitalismo pré-monopolista ao capitalismo monopolista e imperialista que levará os Estados Unidos a se lançarem sobre a América Latina, primeiramente, e depois sobre o mundo "[ [...] e verifica, assim, a diferença de estrutura e espírito entre as duas Américas” (RETAMAR, 1983, p. 18).

Em 1878, ano em que houve um acordo de paz com relação à guerra dos dez anos, Martí volta a Cuba e se une ao Comitê Revolucionário Cubano. É novamente deportado no ano seguinte, foge para os Estados Unidos e lá vive até 1895. Nesse tempo, produz vários escritos, dentre eles Nuestra América (1891), no qual Martí reflete sobre a identidade da América Latina e a contrapõe à América anglo-saxã, bem como retoma algumas ideias de seu discurso Madre América (1889), apresentando os princípios que os países latino-americanos deveriam adotar para terem unidade (Villaça, 2008).

A inovação seria o norte nesse processo, Cuba, o timoneiro, e todos deveriam desenvolver a consciência das particularidades e peculiaridades da América Latina, proposição última defendida por Bolívar e por Simon Rodríguez, educador venezuelano cujas ideias Martí teve contato em sua passagem por aquele país. Por fim, a educação mantinha-se como pedra fundamental para gerar os valores pátrios e bons governos. 
Com o final da guerra chiquita, Martí é nomeado presidente interino do Comitê Revolucionário Cubano (1881) e dedica-se com afinco ao esforço de turbinar o movimento pela independência de Cuba, além de publicar artigos alertando quanto às limitações das grandes nações metropolitanas (Escenas Norteamericanas). Graças à sua habilidade oratória e carisma, consegue tornar-se líder da comunidade cubana de exilados, cada vez maior, minimizando divergências (como as que existiam entre os generais refugiados Máximo Gómez e Antonio Maceo e mesmo entre os diferentes grupos que formavam a comunidade cubana) e defendendo a unidade, a tolerância, a inclusão social e a convivência harmoniosa entre as raças (Villaça, 2008). Dois exemplos de discurso, ambos ocorridos em 1891, são Con todos y para El bien de todos, em que Martí reforça a unidade proposta e incita o povo cubano à luta e Los Piños Nuevos, uma homenagem aos oito estudantes de medicina fuzilados em 1871 pelo regime da metrópole.

Em 1892, Martí redige as bases do Partido Revolucionário Cubano, criado para conquistar a independência de Cuba e que foi, em realidade, além — anunciou, no dizer de Retamar (1983), "as vanguardas políticas que guiariam as guerras revolucionárias deste século" (RETAMAR, 1983, p. 25). No jornal Patria, criado por Martí, publica as ideias do partido e divulga a carta da independência. Troca várias correspondências com o general Gómez e, em 25 de março de 1982, lança com ele o Manifiesto de Montecristi, em que expõem ao mundo seus objetivos de independência e como fariam para libertar Cuba da Espanha (Retamar, 1983; Villaça, 2008).

Em 1895, Martí regressa a Cuba, com o General Gómez e, no caminho, para encontrar com o General Maceo são surpreendidos por tropas espanholas em Dos Ríos, local em que Martí sai a combate e morre fuzilado. A luta pela independência continuou e a libertação ocorreu, de fato, após a intervenção norte-americana que lutou contra a Espanha a pretexto de ter sido atacado por tropas espanholas na misteriosa explosão do encouraçado Maine, navio norte-americano ancorado em Havana.

Até 1902, Cuba foi governada por generais norte-americanos e, mesmo após a independência, houve outras intervenções norte-americanas, interrompidas com a revolução liderada por Fidel Castro, em 1959. Antes, em 1953, Fidel havia tentado um assalto ao quartel Moncada, sem sucesso. Ao ser preso e indagado sobre quem fora o autor intelectual dessa ação, Fidel responde: "É José Martî" (RETAMAR, 1983, p. 13).

No dizer de Retamar (1983), Martí apresentou uma universalidade em sua obra, universalidade esta advinda de várias realidades: "enquanto no plano imediato organiza a guerra de Cuba contra a Espanha, no imediato, tenta precaver-se contra a expansão dos Estados Unidos." (RETAMAR, 1983, p. 37.) Mais adiante, conclui: "Martí conheceu uma tensão histórica que nenhum outro hispano-americano viveu: conclui a obra do século XIX, prepara e inicia a do XX." (RETAMAR, 1983, p. 37.)

\section{Bolívar e Martí — obras comparadas}

Retamar (1983), comparando Bolívar e Martí, escreve:

Outro grande criador da América Latina, Simon Bolívar (1783-1830) havia notado que "nós somos um pequeno gênero humano": que não somos prolongamento ou eco 
da Europa Ocidental, mas outra coisa, outro mundo. Martí vai mais longe que Bolívar ao reparar não só nessa diferenciação, como também no parentesco estrutural que nos une a outras sociedades ao longo do planeta; neste sentido, provavelmente tenha sido o primeiro a assinalar a unidade de problemas do homem "que não é da Europa ou da América europeia”. (RETAMAR, 1983, p. 33.)

\section{Quadro 1 - Falta de compreensão da Realidade} LOCAL E ADOÇÃO DE PRINCÍPIOS E CÓDIGOS ESTRANGEIROS

\begin{tabular}{|c|c|}
\hline Bolívar & José Martí \\
\hline $\begin{array}{l}\text { Como citado anteriormente, em Manifiesto de } \\
\text { Cartagena, escrito em 1812, Bolívar aponta as } \\
\text { causas que levaram à queda da primeira república } \\
\text { em menos de um ano. O primeiro erro foi tolerar as } \\
\text { resistências contra a independência, sustentando-se } \\
\text { os magistrados em uma interpretação equivocada } \\
\text { do conceito de humanidade e em consultas a códigos } \\
\text { formados por visionários: "tivemos filósofos a fazer } \\
\text { de chefes, filan tropia em vez de legislação, } \\
\text { dialéctica por táctica e sofistas por soldados." } \\
\text { (BOLÍVAR, Manifesto de Cartagena, 1812, ed. } \\
\text { 1977, p. 58.) Baseando-se na história de outros } \\
\text { países, os estadistas consideravam dispensável a } \\
\text { formação de milícias pagas para manter a liberdade } \\
\text { da pátria. Bolívar critica essa postura e a acusa de } \\
\text { ser derivada de um raciocínio de quem não conhece } \\
\text { a realidade dos povos, bem como as diferenças de } \\
\text { tempos e costumes. A adoção do federalismo como } \\
\text { forma de governo também foi a importação de } \\
\text { um modelo que não servia para aquele momento } \\
\text { de independência dos países latino-americanos. } \\
\text { Ademais, não havia termo de comparação entre } \\
\text { os Estados Unidos e os países latino-americanos, } \\
\text { muito diferentes em sua concepção e construção: } \\
\text { "É aqui que devemos encontrar o código que nos serve, } \\
\text { e não em Washington!" (BOLÍVAR, Discursos de } \\
\text { Angostura, 1819, ed. 1977, p. 121.) }\end{array}$ & $\begin{array}{l}\text { Em Nuestra América (1891), Martí defende, de } \\
\text { maneira contundente, a construção da América com } \\
\text { base nos princípios e conhecimentos originais, } \\
\text { observando que a incapacidade de conduzir esses } \\
\text { povos das repúblicas nascentes não está no povo, } \\
\text { mas nos que desejam reger tais nações "[...] com } \\
\text { leis herdadas de quatro séculos de prática livre } \\
\text { nos Estados Unidos e de dezenove séculos de } \\
\text { monarquia na França" (MARTÍ, Nossa América, } \\
\text { 1891, ed. 1983,p. 195). Martí relembra que o espírito } \\
\text { do governo deve ser o do próprio país de origem } \\
\text { e que apenas conhecendo seu país um governo } \\
\text { pode livrá-lo de tiranias. "[...] o bom governante } \\
\text { na América não é o que sabe como se governam o } \\
\text { alemão e o francês, mas sim aquele que sabe de } \\
\text { quais elementos está constituído seu país" } \\
\text { (MARTÍ, Nossa América, 1891, ed. 1983, p. 195.) } \\
\text { Dentre os grandes erros da América Latina, a } \\
\text { Nossa América em comparação à outra (a América } \\
\text { do Norte), Martí destaca a importação excessiva de } \\
\text { ideias e fórmulas estrangeiras. "nem o livro euro- } \\
\text { peu, nem o livro ianque davam a chave do enigma } \\
\text { hispano-americano." (MARTÍ, Nossa América, 1891, } \\
\text { ed. de 1983, p. 199); ou, ainda, "A independência } \\
\text { da América vinha sangrando há um século: - } \\
\text { nem de Rousseau nem de Washington vem nossa } \\
\text { América, senão de si mesma"! (MARTÍ, Bolivar, } \\
\text { 1893, ed. de 1983, p. 241.) }\end{array}$ \\
\hline
\end{tabular}

Fonte: a própria autora, com base nos escritos de Bolívar e José Martí.

\section{Quadro 2 - Forma e Papel de Governo}

\begin{tabular}{|c|c|}
\hline Bolívar & José Martí \\
\hline $\begin{array}{l}\text { Considerando a história dos povos latino-americanos } \\
\text { e sua situação à época, Bolívar defende a existência de } \\
\text { um governo paternal, nem uma monarquia universal, } \\
\text { nem uma grande república. (Carta de Jamaica, 1815.) } \\
\text { O Governo deve compreender as circunstâncias do } \\
\text { momento e agir sobre elas de acordo com que reque- } \\
\text { rem, não somente as circunstâncias, mas também o } \\
\text { tempo e os homens que o compõem (Manifesto de }\end{array}$ & $\begin{array}{l}\text { Em Nuestra América (1891), Martí defende que a } \\
\text { forma de governo deve estar de acordo com a cons- } \\
\text { tituição do próprio país, visto que o governo é o } \\
\text { resultado de um equilíbrio entre os elementos na- } \\
\text { turais que constituem cada nação. Em Con Todos y } \\
\text { para El Bien de Todos (1891), Martí apresenta em } \\
\text { um discurso carregado de emoção as bandeiras de } \\
\text { união dos cubanos: a luta pela independência deve }\end{array}$ \\
\hline
\end{tabular}


Cartagena, 1812). Identificamos, em Discursos de Angostura (1819), novo reforço à ideia de que o Governo bom é o que conhece seu povo. (Bolívar, 1819, ed. de 1977 , p. 129.) Ao final da vida, já desiludido e sem conseguir executar sua proposição de união dos vice-reinos da América do Sul, Bolívar escreve ao General O'Learly (1829), irlandês que foi seu ajudante de campo, e comenta que a extensão territorial exigiria uma de duas formas de governo, opostas e contrárias, em seu ponto de vista, ao bem do país: a autoridade real ou a liga geral, sendo que entendia ser a monarquia uma escolha impossível pela constituição democrática do país, pelas diferenças sociais significativas que trariam dissensões, pela fragilidade que a monarquia teria em face ao respeito que os generais têm pelos seus pares. Defendia um governo central, proporcional à extensão do território da Colômbia e à índole do povo. (Discurso Perante o Congresso Constituinte da Bolívia, 1825, ed. de 1977 , p. 157.) Um governo vitalício, sempre de acordo com a opinião pública, que tivesse mais solidez e mais energia do que o que era necessário em outros países, um governo que tivesse autoridade e mão for te para assegurar a existência da nação. Para tanto, era preciso, após um tempo longo de lutas para a defesa da nação, que os dirigentes parassem para pensar de forma concreta em como governar considerando a debilidade dos laços sociais, a dimensão do território e as peculiaridades da nação. Em um de seus últimos escritos, a Carta a Juan José Flores (1830), Bolívar demonstra sua amargura e descrença pelo futuro das nações americanas considera-as ingovernáveis, fadadas a serem governadas por "tiranetes", destinadas à demagogia e ao descalabro resultante da ferocidade e da ideologia exagerada (ver: Bolívar, 1830, ed. de 1977, p. 191-192). Todas as repúblicas que procuraram ser absolutamente democráticas foram frustradas. Assim, Bolívar defende uma república forte (a que possua um executivo forte), que tenha por base a soberania do povo, aqui entendida como um regime fundado na divisão dos poderes, na liberdade civil, na eliminação da escravidão (igualdade), "na abolição da monarquia e dos privilégios" (BOLÍVAR, 1819, Discursos de Angostura. In: Escritos Políticos, ed. de 1977, p. 126). estar baseada na criação de uma república que tenha como princípio, como lei primeira, a dignidade plena do homem e o exercício dessa integridade e do respeito, o trabalho de cada um e o pensar original. No dizer de Martí: "O la república tiene por base el carácter entero de cada uno de sus hijos, el hábito de trabajar con sus manos y pensar por sí propio, el ejercicio íntegro de sí y el respeto, como de honor de familia, al ejercicio íntegro de los demás; la pasión, en fin, por el decoro del hombre, - o la república no vale una lágrima de nuestras mujeres ni una sola gota de sangre de nuestros bravos." (MARTÍ, 1891, Con todos y para el bien de todos, s/p.) A república deve refletir a originalidade de Cuba, não ser apenas uma mudança de forma, tampouco a continuação da visão colonial com nova bandeira alienígena, mas sim ser um bastião da igualdade (Con todos y para el bien de todos, 1891). Como aponta Martí em Mi Raza (1893), a República cubana será forjada da luta e da união dos que lá vivem, sejam negros, espanhóis nascidos na ilha, que lá habitam. Em todos seus escritos, vemos a convocação para a ação de construção da República e para a unidade de raças, as quais, para Martí, não apresentam prerrogativas de superioridade ou inferioridade (ver Mi Raza, 1893). A unidade é pela pátria, e deve-se lutar para constituí-la livre; afinal, como o próprio Martí afirma, esperar na alma não funda povos. (Con todos y para el bien de todos, 1891). A República deve, então, ser uma construção de todos. Do homem mais douto ao mais simples, todos exercem um exercício contínuo de suas capacidades na República que Martí defende. (El tercer año del Partido Revolucionario Cubano, 1894.) Em tempos diferentes dos vividos por Bolívar, a República de Martí apresenta uma proposta menos centralizadora e mais consoante com os novos anseios e as estruturas que se compunham no final do século XIX. Como afirma o próprio Martí, é preciso ter visão e marchar com o mundo. (El tercer año del Partido Revolucionario Cubano, 1894.)

Fonte: a própria autora, com base nos escritos de Bolívar e José Martí. 


\section{Quadro 3 - Forma de Estado e a Crítica ao Federalismo}

\begin{tabular}{|c|c|}
\hline & Jos \\
\hline $\begin{array}{l}\text { O principal erro que causou a volta do domínio } \\
\text { espanhol na Venezuela foi, para Bolívar, a adoção do } \\
\text { federalismo. Embora considerado o mais perfeito } \\
\text { para proporcionar a felicidade humana em sociedade, } \\
\text { como apontado anteriormente, o federalismo não se } \\
\text { aplicava àquele momento de formação dos Estados } \\
\text { latino-americanos; tampouco era um ponto forte } \\
\text { dos Estados Unidos }{ }^{(1)} \text {. A rejeição ao federalismo } \\
\text { como forma de governo acompanha a vida de } \\
\text { Bolívar, embora possamos observar, em 1824, em } \\
\text { carta escrita Aos Governos das Repúblicas da Colôm- } \\
\text { bia, México, Rio de La Plata, Chile y Guatemala, que } \\
\text { Bolívar compreende ser uma base fundamental de } \\
\text { união e de perenidade dos governos independentes } \\
\text { a existência de uma assembleia de plenipotenciários, } \\
\text { tendo, para tanto, convidado os governos do México, } \\
\text { Peru, Chile e Buenos Aires a formarem uma confede- } \\
\text { ração com a Colômbia. (Bolívar, } 1824 \text {, Aos Governos } \\
\text { das Repúblicas da Colômbia, México, Río de La } \\
\text { Plata, Chile e Guatemala. In: Escritos Políticos, ed. de } \\
1977 \text {,p. 17o.) Também encontramos, em 1826, uma } \\
\text { proposição de federação geral entre Bolívia, Peru e } \\
\text { Colômbia, mais unida do que a norte-americana, } \\
\text { sob a direção de um presidente e de um vice-presi- } \\
\text { dente, como forma de evitar a dissolução e divisão } \\
\text { que acontecia nas nações que haviam conquistado } \\
\text { sua independência. Percebe-se a incomodação de } \\
\text { Bolívar com os problemas que ocorriam e que pode- } \\
\text { riam levar à perda do trabalho em prol da unidade } \\
\text { sonhada e duramente conquistada, bem como se } \\
\text { observa sua incomodação com a própria proposta, } \\
\text { único remédio que encontrou, após muito pensar, } \\
\text { para evitar o mal maior que era a dissolução da } \\
\text { unidade }(2) \text { Em Earta enviada a Sucre, Marechal de } \\
\text { Ayacucho, Bolívar deixa claro que o pacto federativo }\end{array}$ & $\begin{array}{l}\text { Para Martí, a construção de um Estado, de uma } \\
\text { nacionalidade, e fruto de ódio e de amor, sendo que } \\
\text { suas formas públicas se expressam, respectivamente, } \\
\text { pelo privilégio e pelo interesse. Um povo é fruto } \\
\text { da composição de várias vontades e é preciso ter } \\
\text { compreensão da dimensão e do tempo históricos } \\
\text { para que esse povo possa ter a liberdade real, isto } \\
\text { é, ser livre para exercer seu próprio modo de } \\
\text { ser.Martí não critica o federalismo em si, mas sim } \\
\text { a nova forma de escravidão ou colonialismo que } \\
\text { ameaça a Nossa América com o surgimento do } \\
\text { imperialismo. Adverte, pois, quanto às mazelas } \\
\text { que os Estados Unidos também possuíam e que } \\
\text { eram destacadas apenas como problemas dos páses } \\
\text { latino-americanos (como podemos ver em escritos } \\
\text { como La verdad sobre los Estados Unidos (1894), } \\
\text { Congreso Internacional de Washington (1889), den- } \\
\text { tre outros. Novamente, devemos ressaltar que o } \\
\text { tempo histórico vivido por Martí foi diferente do } \\
\text { vivido por Bolívar. Nos fins do século XIX, as nações } \\
\text { praticamente já estavam estruturadas em sua forma } \\
\text { de Estado; a discussão tomava um eixo em que a } \\
\text { economia passava a preponderar e influenciar na } \\
\text { autonomia política dos países.Com esse pano de } \\
\text { fundo, observamos que Martí alerta veementemente } \\
\text { quanto à cobiça que os Estados Unidos apresentavam } \\
\text { sobre Cuba; defendendo uma revolução que não seja } \\
\text { amparada no apoio ambivalente da América do } \\
\text { Norte. (ver, por exemplo, El tercer año del Partido } \\
\text { Revolucionário Cubano, de 1884). Para ele, Cuba e } \\
\text { Porto Rico, as duas últimas naçães a buscarem a } \\
\text { independência, tinham uma responsabilidade vista } \\
\text { como maior do que as das outras nações que já esta- } \\
\text { vam independentes, dado o momento histórico. } \\
\text { Aliás, libertar-se do domínio econômico dos Estados }\end{array}$ \\
\hline
\end{tabular}

(1) No dizer de Bolívar: “(...) este pueblo es único en la historia del género humano es un prodigio, repito, que un sistema tan débil y complicado como el federal haya podido regirlo en circunstancias tan difíciles y delicadas como las pasadas. Pero sea lo que fuere de este gobierno con respecto a la nación norteamericana, debo decir, que ni remotamente ha entrado en mi idea asimilar la situación y naturaleza de los Estados tan distintos como el inglés americano y el americano español." (BOLÍVAR, 1819, Discursos de Angostura, s/p. Disponível em: <http://www.analitica.com/bitblio/bolivar/angostura.asp >.)

(2) Assim escrevia Bolívar: "A intenção deste pacto é as da mais perfeita unidade sob uma forma federal. O governo dos estados federados ou particulares caberá ao vice-presidente com as suas duas câmaras em tudo o que se refere a religião, justiça, administração civil, economia e, finalmente, tudo aquilo que não se relacione com guerra ou relações externas. (...) O Libertador, como chefe supremo, visitará todos os anos os departamentos de cada estado. A capital será um ponto central (...) medite por instantes nas vantagens que nos advirão dessa federação geral; medite nos males de que ela nos poderá livrar e não lhe será difícil descobrir quanto interesse deveremos todos ter por um tal plano que assegura a liberdade na América, unida na ordem e na estabilidade." (BOLÍVAR, 1826, Carta ao General D. António Gutiérrez de La Fuente. In: Escritos Políticos, ed. de 1977, p. 179-181.) Idênticas recomendações são encontradas, também, na Carta a Sua Exa. o Grande Marechal de Ayacucho, António José de Sucre, missiva enviada dois meses após à carta remetida a de La Fuente, em 1826. 
é a alternativa para evitar a dissolução da República. (Bolívar, 1826, Carta A Sua Exa. O Grande Marechal de Ayacucho, António José de Sucre. In: Escritos políticos, ed. de 1977 , p. 174-175.) No entanto, em um de seus últimos escritos, a carta ao general O'Learly, Bolívar mantém suas críticas ao Federalismo, considerada uma forma de governo anárquica. (Bolívar, 1829, Carta a Daniel Florêncio O'Learly. In: Escritos políticos, ed. de 1977, p. 183.)
Unidos era visto, para Martí, como a segunda independência da América espanhola.

Fonte: a própria autora, com base nos escritos de Bolívar e José Martí

\section{Quadro 4 - Olhares sobre a América latina: Liberdade, Educação e Cidadania}

\begin{tabular}{|c|c|}
\hline Bolívar & José Martí \\
\hline $\begin{array}{l}\text { A liberdade é algo que se busca sempre, mas não se } \\
\text { alcança o equilíbrio, que seria um ponto de mode- } \\
\text { ração. Para Bolívar, a defesa de liberdade ilimitada } \\
\text { é uma quimera e um perigo, porque vê que a falta de } \\
\text { restrição conduz ou à anarquia ou ao despotismo. } \\
\text { (Bolívar, 1819, Discursos de Angostura. In: Escritos } \\
\text { políticos, ed. de 1977, p. 138-139.) Suas ideias ex- } \\
\text { pressam, em vários momentos, as propostas de } \\
\text { Rousseau - vejamos apenas um trecho para exem- } \\
\text { plificar, extraindo alguns comentários do pensador } \\
\text { genebrino sobre a importância da divisão e do equi- } \\
\text { líbrio entre os poderes: "Si el soberano quiere } \\
\text { gobernar, o el magistrado dar leyes, o si los súditos } \\
\text { se niegan a obedecer, el desorden sucede a la regla, } \\
\text { la fuerza y la voluntad ya no actuán de acuerdo y el } \\
\text { Estado, al desintegrarse, cae en el despotismo o } \\
\text { en la anarquía." (ROUSSEAU, 1762. Du Contrat } \\
\text { Social. In: ROUSSEAU, Jean-Jacques. El contrato } \\
\text { social. Discursos. 1. ed. Buenos Aires: Losada, 20o8.) } \\
\text { Também como Rousseau, a educação tem um papel } \\
\text { de destaque na visão do Libertador. Um povo sem } \\
\text { educação, ignorante, é considerado como o "ins- } \\
\text { trumento de sua própria destruição" (BOLÍVAR, } \\
\text { Discursos de Angostura, 1819, ed. de 1977, p. 116). } \\
\text { "A educação popular deve ser o cuidado primogênito } \\
\text { do amor paternal do Congresso. Moral e luzes são }\end{array}$ & $\begin{array}{l}\text { Martí fez um discurso em homenagem a Simon } \\
\text { Bolívar em 1893. Nele, vemos o reconhecimento } \\
\text { pelo trabalho de Bolívar em prol da liberdade e de } \\
\text { como esse desejo de liberdade reverberou pelos } \\
\text { povos da America Latina }{ }^{(3)} \text {. Martí via em Bolívar } \\
\text { alguém em que a alma do continente penetrou em } \\
\text { profundidade, alguém a quem a Nossa América deve } \\
\text { reconhecer e dar valor no processo de emancipação } \\
\text { das colônias. Em sua obra Con todos y para el bien de } \\
\text { todos, Martí defende a liberdade de Cuba com galhar- } \\
\text { dia - A independência de seu país é uma ode à pá- } \\
\text { tria(4). Com relação à Educação, Martí é um defensor } \\
\text { desta para todos, de forma igualitária e baseada na } \\
\text { realidade de cada nação e que possa auxiliar na } \\
\text { práxis libertadora do homem em sua construção } \\
\text { de cidadão (Nuestra América, } 1891 \text {, ed. de } 1983 \text { ). Em } \\
\text { Maestros Ambulantes (1884), Martí destaca a educa- } \\
\text { ção como um alimento essencial ao crescimento do ser } \\
\text { humano, como algo singelo que estrutura a grandeza } \\
\text { de uma pátria. Mais uma vez, a educação é associada } \\
\text { à liberdade; ser culto é o único modo de ser livre, na } \\
\text { visão de Martí. Os professores ambulantes, citados } \\
\text { no referido artigo, são os que levam o conhecimento } \\
\text { ao homem do campo, como quem professa uma re- } \\
\text { ligião; como os que abrem o apetite para o saber, } \\
\text { um saber conectado com a realidade que se vive. }\end{array}$ \\
\hline
\end{tabular}

(3) Martí, comentando sobre Bolívar: “(...) somos os filhos de sua espada. (...) Aquele foi um homem realmente extraordinário. Viveu como entre chamas, e ele o era. (...) Sua glória o circunda, inflama e arrebata. (...) Não desata raças, não desencanta o continente, não evoca povos, não percorreu com as bandeiras da redenção mais mundos que qualquer conquistador com as da tirania, não fala, do Chimborazo, com a eternidade e não tem a seus pés no Potosí, sob o pavilhão da Colômbia, bicado de condores, uma das obras mais bárbaras e tenazes da história humana?" (MARTí, 1893, Bolívar. In: Nuestra América, ed. de 1983, p. 240-241.)

(4) "Cubanos: Para Cuba que sufre, la primera palabra. De altar se ha de tomar a Cuba, para ofrendarle nuestra vida, y no de pedestal, para levantarnos sobre ella. (...) Porque si en las cosas de mi patria me fuera dado preferir un bien a todos los demás, un bien fundamental que de todos los del país fuera base y principio, y sin el que los demás bienes serían falaces e inseguros, ese sería el bien que yo prefiriera: yo quiero que la ley primera de nuestra república sea el culto de los cubanos a la dignidad plena del hombre." (MARTí, 1891, Con todos y para el bien de todos, s/p. Discurso proferido no Liceo Cubano, em Tampa, Flórida. Disponível em: <http://www.josemarti.info/documentos/con_todos.html >). 
os polos de uma República; moral e luzes são as nossas primeiras necessidades." (BOLÍVAR, Discursos de Angostura, 1819, ed. de 1977, p. 140-141.)

Fonte: a própria autora, com base nos escritos de Bolívar e José Martí.

\section{Bolívar e Martí - Ideias singulares E atuais dos PENSAdores Para a América Latina}

Dentre as proposições desses dois atores-pensadores da América Latina, destacamos alguns pontos por sua originalidade e visão antecipada que, até os dias atuais, ressoam na América Latina. De Bolívar, sua proposta de Constituição e composição de poderes é um destaque. Em seu Discurso perante o Congresso Constituinte da Bolívia (1825), Bolívar destaca ser a função do legislador um ministério divino. Embora consciente de que não há lei perfeita, Bolívar vê a Constituição como instrumento essencial para que se possa dirigir homens livres, como arma que os legisladores têm para combater a tirania e a anarquia. Mais adiante, em 1826, Bolívar reforça a Constituição como o grande motor da reforma social e como peça fundamental para a estruturação do governo (ver: BOLÍlVAR, 1826 Carta a Sua Exa. o Grande Marechal de Ayacucho, Antonio José de Sucre. In: Escritos políticos, ed. de 1977, p. 174); como a tábua de salvação para evitar a desintegração das recém-independentes nações (ibidem, p. 178).

Já em 1819, em seus Discursos de Angostura, encontramos a mesma defesa da Constituição como ponto de fixação da liberdade. Uma proposição que aparece nos dois discursos é a da divisão de quatro poderes políticos: executivo, legislativo, judiciário e moral. O poder moral é aquele "cujo domínio seja a infância e o coração dos homens, o espírito público, os bons costumes e a moral republicana” (BOLÍVAR, 1819, Discursos de Angostura. In: Escritos políticos, ed. de 1977, p. 141).

No discurso de 1826, cabe ressaltar a importância dada à participação do cidadão por meio de processos eleitorais e da representatividade - cada dez cidadãos nomeiam um eleitor e este não precisa ter posses, mas ser honrado e saber ler e escrever. Também em 1826, a estrutura dos poderes e suas atribuições apresentam-se melhor definidas do que em 1819. Vemos que, enquanto em 1819, Bolívar comenta que os libertadores da Venezuela deveriam ocupar altos postos por seus esforços e sacrifícios pela Independência, em 1826, claramente Bolívar defende uma estrutura de mando na qual o posto principal cabe ao libertador.

Em 1819, Bolívar destaca o modelo britânico de governo executivo e propõe um modelo em que o povo ou seus representantes o nomeiem; deve esse presidente governar com o auxílio da Constituição e submissão às leis. Porém, o Executivo precisará ter vigor e meios para que possa manter-se à altura de enfrentar os entraves e resistências que sempre derivarão da oposição entre os três poderes clássicos (Executivo, Legislativo, Judiciário) e o povo (ver: BOLÍVAR, 1819, Discursos de Angostura. In: Escritos políticos, ed. de 1977, p. 135-136).

Em 1826, seu discurso é mais focado e preciso: o poder central cabe ao Presidente da República que deve ser vitalício. Sua metáfora é comparar o Presidente ao Sol e ao ponto fixo de Arquimedes, com o qual se pode mover o mundo. Esse ponto central, no entanto, 
não é visto como despótico ou como ameaça à democracia, porque Bolívar entende que as três Câmaras com funções específicas restringem as ações executivas do Presidente de uma forma favorável ao povo, visto que estas ações ficam limitadas, constitucionalmente, à nomeação de funcionários da fazenda, da paz e da guerra e ao comando do exército (ver: BOLÍVAR, 1825, Discurso perante o Congresso Constituinte da Bolívia. In: Escritos políticos, ed. de 1977, p. 155-157). O vice-presidente tem por papel obedecer ao Executivo - de quem recebe ordens - e ao Legislativo — de quem recebe as leis.

Como no modelo norte-americano, Bolívar adota que o primeiro-ministro deva ser o sucessor do presidente, por já estar aquele experiente nas questões do Estado. Deve ser esse vice-presidente, nomeado pelo presidente, também impoluto e obedecer cegamente às leis constitucionais. Para Bolívar, essa estrutura política com presidente vitalício e vice-presidente hereditário garante a conservação da ordem e a subordinação entre os cidadãos, trazendo, assim, as vantagens que se podiam encontrar na monarquia, excluindo-se as desvantagens que tal sistema de governo traz e que, como já apontamos anteriormente, era considerado inadequado para a América.

Ser o presidente vitalício é uma defesa que encontramos no discurso de Bolívar de 1826, refletindo uma mudança se compararmos esta argumentação de 1826 com a de 1819 , realizada nos Discursos de Angostura. Em 1819, Bolívar era favorável a eleições frequentes, para evitar a usurpação, a tirania e o fim dos governos democráticos. (Ver: BOLÍVAR, 1819, Discursos de Angostura, ed. de 1977, p. 113-114).

Nos dois discursos (1819 e 1826), como já destacamos, vemos a defesa de um governante com pulso firme para poder controlar a diversidade de origens do povo latino-americano e para dar mais solidez à democracia, forma de governo considerada débil. A unidade deve ser a marca do governo. Unidade esta que é tão presente nos escritos de Bolívar que levam historiadores, como Fredrigo (2007) a comentar:

[...] posição ocupada na guerra consagrou Simón Bolívar como herói americano. Nessa perspectiva, o general ultrapassou as fronteiras da Venezuela, sendo o personagem mais lembrado e associado à defesa e à vitória da independência na América Hispânica. Ao lado dessa referência, não há discussão sobre a unidade americana que não mencione Simón Bolívar. Das inúmeras leituras sobre a América Latina, nenhum tema foi tão candente como o da unidade latino-americana. Acrescente-se ao anterior que, durante longas décadas, refletir sobre a unidade também esteve associado ao desejo de encontrar uma identidade americana. (FREDRIGO, 2007, p. 314.)

Um ponto de destaque no discurso de Bolívar de 1826 é como o libertador vê, à frente de sua época, a necessidade de haver accountability na área pública, instando aos legisladores o estabelecimento de leis que determinem um método de responsabilidade dos agentes públicos (ver: BOLÍVAR, 1825, Discurso perante o Congresso Constituinte da Bolívia. In: Escritos políticos, ed. de 1977, p. 162).

Quanto às garantias, em 1826, Bolívar destaca a liberdade civil (considerada a verdadeira liberdade), a segurança pessoal (fim da sociedade) e a igualdade (a lei das leis), sendo que esta implica a eliminação da escravidão (ver: BOLÍVAR, 1825, Discurso perante o Congresso Constituinte da Bolívia. In: Escritos políticos, ed. de 1977, p. 162-163). Sugere, ainda, que a 
religião não seja âmbito constitucional, pois é uma questão de foro íntimo. O progresso moral do cidadão é que deve ser objeto de lei. O direito de um cidadão é, para Bolívar, a posse de exercer suas virtudes políticas.

Se no discurso de 1826 a liberdade recebeu mais detalhes, a igualdade teve sua primazia no discurso anterior, de 1819. Em Discursos de Angostura (1819), Bolívar defende que compete às leis corrigir as diferenças naturais entre os homens para que haja igualdade, de quem depende o princípio fundamental do sistema político proposto (ver: BOLÍVAR, 1819, Discursos de Angostura. In: Escritos políticos, ed. de 1977, p. 126).

Sua defesa da unidade e sua visão de uma grande América unida impactam até a atualidade os líderes latino-americanos, dentre os quais um exemplo de associação costumeira com a figura do Libertador com fins de reforçar o patriotismo e a ideia de uma Grande América se apresenta na Venezuela, com o governo de Hugo Chávez. A Constituição atual do país foi denominada "Bolivariana" e busca trazer os princípios defendidos por Bolívar.

Los ciclos en los que se desenvuelve la historia constitucional venezolana para algunos de nosotros son seis, pero de esos seis hay tres ciclos que son fundamentales. El ciclo de los actos fundacionales de la República, es decir, el Acta de la Independencia, la Declaración de los Derechos del Pueblo y la Constitución de diciembre de 1811. Ese ciclo paradigmático para nosotros, porque no sólo fue un acta de bautizo constitucional, sino la expresión de nuestro pueblo objetivada en su identidad nacional, y en el deseo de ser una entidad libre y autónoma, hace nacer otro ciclo que es el Bolivariano. Los tres discursos de Angostura: 1817, creación del Consejo de Estado; 1818, Convocatoria al Congreso Constituyente, y el Discurso Exposición de Motivos de la Constitución del año 19, vertebran un sentimiento y una interpretación que de alguna manera va dándole especificidad a nuestras instituciones sociales y políticas. Ese ciclo, por supuesto, sin pretender evaluarlo en este momento, es un ciclo rico en la construcción y en la arquitectura del país, pero también en los grandes prolegómenos políticos y constitucionales. (ESCARRÁ, Hermann. Asamblea Nacional Constituyente — Sesión Ordinaria del día martes 12 de octubre de 1999. Extraído de: <www.asambleanacional.gov.ve>.)

José Martí tinha uma visão de continente que era muito singular e até profética, como defende Altmann (2003). Difícil é expressar a dimensão que suas ideias tomaram, sem se valer de uma série de adjetivos que seria quase infindável. Como afirma Lolo (2007):

A más de siglo y medio del nacimiento de José Martí, se reafirma la solidez del juicio de Gabriela Mistral al calificar la obra del patriota cubano como una "mina sin acabamiento". Los estudios sobre el corpus martiano, luego de un tímido inicio estando Martí vivo todavía, se han multiplicado proporcionalmente al tiempo transcurrido desde entonces. A veces se trata del resultado de una nueva lectura de obras conocidas; otras, del descubrimiento de una pieza olvidada que explica o ilumina trabajos anteriores o pasajes de su propia vida. Críticos e historiadores encuentran siempre una veta inexplorada o poco conocida que reafirma o complementa lo que se sabía, pone de manifiesto algo desconocido, o confirma lo que era hasta entonces sólo intuición o conjetura. [...] En todos los casos, se trata de un cavar profundo que se ha extendido por varias generaciones. Dieron los primeros golpes de pico e historia sus amigos y discípulos directos. Han seguido el esfuerzo estudiosos y admiradores a más de un 
siglo de distancia y de nacionalidades múltiples. El final es casi siempre luz. Lo cual no es nada raro tratándose de un hombre que dedicó su vida y su talento a combatir las sombras. (LOLO, 2007, p. 1.)

Em 1889, Martí discursa perante a Sociedad Literaria Hispanoamericana e apresenta sua visão de continente - a Mãe América, forjada das lutas e dos povos que aqui se fundiram. A Mãe América merece todo o respeito e o orgulho dos que daqui nasceram ou aqui vivem; uma América que é heroica e trabalhadora. Traz um chamamento aos latino-americanos para reconhecerem os feitos desse continente, sem se diminuírem aos feitos de outros continentes, que possuem sua própria história e méritos. Em Nuestra América, artigo publicado em 1891, Martí defende novamente a unidade dos povos latino-americanos em prol do desenvolvimento de uma própria consciência da latinidade e orgulho dessa latinidade. Incita a América a acordar e lutar para eliminar os estrangeirismos e os "insetos daninhos, que roem o osso da pátria que os nutre” (MARTÍ, 1891, Nuestra América. In: Nossa América. Antologia, ed. de 1983, p. 195). Na língua original:

Cree el aldeano vanidoso que el mundo entero es su aldea, y con tal que él quede de alcalde, o le mortifique al rival que le quitó la novia, o le crezcan en la alcancía los ahorros, ya da por bueno el orden universal, sin saber de los gigantes que llevan siete leguas en las botas y le pueden poner la bota encima, ni de la pelea de los cometas en el Cielo, que van por el aire dormidos engullendo mundos. Lo que quede de aldea en América ha de despertar. Estos tiempos no son para acostarse con el pañuelo a la cabeza, sino con las armas de almohada, como los varones de Juan de Castellanos: las armas del juicio, que vencen a las otras. Trincheras de ideas valen más que trincheras de piedra. (MARTÍ, 1891, Nuestra América, s/p. Disponível em: <http://www.josemarti.info/ documentos/nuestra_america.html>.)

Preocupa a Martí a falta de visão política e a ignorância quanto aos reais perigos que a Nossa América enfrentava ao ficar passiva e desunida; com precisão, desenha o quadro da problemática à época e propõe, como solução para essas questões, o desenvolvimento de uma estratégia própria, que busque soluções próprias, com unidade.

A relação com os Estados Unidos é outro ponto que merece destaque nos escritos de Martí. Ele aponta, ainda discorrendo sobre a América do Norte, como o maior perigo que a Nossa América haveria de enfrentar o desprezo e o desconhecimento dos Estados Unidos sobre os países vizinhos (ver: MARTÍ, 1891, Nuestra América, s/p. Disponível em: <http:// www.josemarti.info/documentos/nuestra_america.html>). Martí era favorável à aproximação dos povos, à não incitação ao ódio; entretanto, alertava quanto à necessidade de se prever, ponderar e avaliar propostas e ter sabedoria e conhecimento para discernir o que se apresenta.

A política, afirma Martí, é uma arte da combinação entre fatores diversos ou opostos de uma nação e o saber desvencilhar-se de uma inimizade aberta ou de uma amizade cobiçosa de outras nações (MARTÍ, 1891, La Conferencia Monetaria de las Repúblicas de la América). Se há uma característica em política que deva ser considerada como essencial, esta é a prevenção. "Gobernar no es más que prever. Antes de unirse a un pueblo, se ha de ver qué daños, o qué beneficios, pueden venir naturalmente de los elementos que lo componen." (MARTÍ, 1891, La Conferencia Monetaria de las Repúblicas de la América, s/p. Extraído de: <http://www.josemarti.info/documentos/conferencia_monetaria.html>). 
No mesmo texto, Martí demonstra sua visão avançada e defensora da Nossa América em seus escritos e em seus atos e é frequente a crítica aos que supervalorizam o que vem de fora e/ou desvalorizam o original, como podemos encontrar em seus comentários finais acerca da Conferência Monetária que os Estados Unidos suspenderam, a qual tratava da proposição de criar uma moeda comum. Nesses comentários, Martí expõe a preocupação com a influência econômica excessiva de um país sobre outro, que leva a uma influência política danosa e destaca, mais uma vez, seu pensamento contrário à dominação de uma nação sobre outra. Martí antevê, no final do século XIX, o domínio da economia e seu impacto na política das nações.

Ainda com relação aos Estados Unidos, Martí consegue observar e corajosamente publicar os problemas que a nação norte-americana enfrentava em sua passagem ao capitalismo, como destacamos no início deste trabalho. Embora elogiasse a construção de um Estado democrático e a defesa dos Estados Unidos à liberdade, não deixava de ver o lado ruim do sistema capitalista, que trazia em seu bojo muitas injustiças sociais e um apego ao materialismo. Seus diversos escritos sobre os Estados Unidos demonstram o ponto em que Martí mais evidencia sua visão profética do domínio que o imperialismo teria sobre as nações. Como comenta o historiador Altmann (2003):

A percepção clara do papel histórico do colonialismo (o tigre que morrerá, garras para o ar, soltando fogo pelos olhos) e a previsão precisa da emergência, ao final do século XIX, da nova inflexão colonialista protagonizada pelo imperialismo do século $\mathrm{XX}$ ( $O$ gigante das botas de 7 léguas) revelam um personagem que articula de forma coerente, ainda no século XIX, o pensamento nacionalista revolucionário que está na base dos grandes movimentos sociais da América Latina do século XX. (ALTMANN, 2003, p. 3.)

Martí deixa, portanto, as sementes para a independência de Cuba e para a adoção de suas ideias, tanto por quem está no poder como por quem se encontra dele alijado, como ocorre atualmente em Cuba, onde vemos tanto castristas como não castristas apoiarem-se nas ideias de Martí para defenderem suas posições. Esses variados matizes demonstram o âmbito que as ideias originais de Martí alcançaram e que o tornam presente como pensador latino-americano para a Nossa América.

\section{Considerações FInAIS}

O propósito deste artigo foi apresentar um panorama das ideias de dois dos homens que fizeram a construção do pensamento político latino- americano e buscaram desenvolver uma consciência de nacionalidade: Simón Bolívar e José Martí. Acreditamos que os trechos das obras selecionadas puderam refletir essa concepção própria que ainda hoje reverbera na América, como podemos identificar em ações atuais dos mais diversos governantes. ${ }^{(5)}$

(5) Exemplos: Fidel Castro rende tributo a José Martí. Disponível em: <www.prensa-latina.cu/index.php?option= com_content\& task=view\&id=208794\&Itemid=1>, Expansionismo de Bolívar é delírio de Chávez <http://www.tribunadaimprensa.com.br/? p=10289\&utm_source=twitterfeed\&utm_medium=twitter $>$, Hugo Chávez volta a enterrar os restos mortais de Símon Bolívar <http://g1.globo.com/mundo/noticia/2010/07/chavez-volta-a-enterrar-restos-mortais-de-bolivar.html>. 
A influência do Iluminismo em Bolívar e Martí pode ser vista às vezes diretamente, às vezes na interpretação das ideias. Indiretamente, como apontamos no decorrer da análise comparativa das ideias de Bolívar e Martí, o Iluminismo faz-se presente em suas visões de liberdade e racionalidade. De Rousseau, especificamente, podemos associar o ideal republicano, as ideias de conhecimento experimental, empírico da realidade, a defesa de um modelo social que olhasse para os oprimidos, a importância da educação como fonte de libertação e construção do homem cidadão, a separação entre religião e Estado. Em Emílio, obra de Rousseau sobre a educação, claramente nos recordamos da proposição de desenvolver um candente sentimento de amor à coletividade quando lemos alguns trechos dos escritos de Bolívar e Martí, aqui apresentados. Em Bolívar, especificamente, podemos lembrar a ideia do pacto social defendida por Rousseau em seus discursos e cartas propondo a composição desse pacto para garantir a liberdade e a unidade das nações.

Já Altmann (2003), comenta que Martí viveu uma posição que ele denomina "iluminista rousseniana", na qual se destaca a crença na bondade intrínseca do homem e a importância da educação para a libertação. Porém, maior que a influência do Iluminismo em Bolívar e Martí, há suas próprias construções do Americanismo, de uma visão para a América Latina que não fosse importada de fora e aqui imposta. Como afirma Martí (1891):

El gobierno ha de nacer del país. El espíritu del gobierno ha de ser el del país. La forma del gobierno ha de avenirse a la constitución propia del país. El gobierno no es más que el equilibrio de los elementos naturales del país. Por eso el libro importado ha sido vencido en América por el hombre natural. Los hombres naturales han vencido a los letrados artificiales. [...] (MARTÍ, 1891, Nuestra América, s/p. Extraído de: <http:// www.josemarti.info/documentos/nuestra_america.html>.)

Com relação às leis, Códigos e Constituições, tanto Bolívar quanto Martí também defendiam a criação de códigos que fossem estruturados na história de cada nação, em suas peculiaridades e aprendizados locais. Interessante verificar que, apesar dos cuidados de ter leis "taylor made", na América Latina o que mais observamos, ao longo da história pós-independência, é que, no dizer de Manoel Bomfim, as Constituições são compilações quase abstratas e estranhas ao meio em que se aplicam — "as constituições aplicam-se às sociedades como tabuletas aos armazéns; trocar-se-iam, e ninguém daria pela coisa” (BOMFIM, 1903, ed. de 1993, p. 171). Vê-se, portanto, que quase um século depois dos escritos de Bolívar, a situação na América Latina pouco mudou no tocante à busca de soluções "importadas" para os males da região.

De igual forma, podemos observar, tanto em Martí quanto em Bolívar, a visão de que a América Latina precisava ter governo próprio, nascido das raízes dessas próprias nações, não algo estrangeiro, que poderia, sim, somar, mas nunca gerar. Bomfim (ed. de 1993), em 1903, já nos alertava que a América Latina era caracterizada por buscar a solução nos livros e pelo fato de que todos se contentam com soluções escritas. Quando os dirigentes saíam da rotina irracional, caíam nas aplicações eruditas. Ciência de verdade, baseada na observação, não existia.

Se observarmos atualmente, pouco ou nada desse quadro teve mudança; contudo, ainda que os velhos males continuem se manifestando no continente, o novo americanismo, 
destacado por Lynch (2001), parece-nos muito bem representado por esses dois atores-pensadores, Bolívar e Martí, homens que viram além de seu tempo e que causam impacto no modus operandi da política moderna, como demonstram algumas notícias recentes aqui citadas. Homens que estão, hoy por hoy, tão em voga - ou talvez até mais - do que estavam em seu tempo histórico.

\section{REFERÊNCIAS BIBLIOGRÁFICAS}

BARRETO, Célia de Barros et al. História geral da civilização brasileira. Tomo II: O Brasil Monárquico, v. 1 - O progresso de emancipação. Rio de Janeiro: Bertrand Brasil, 1993.

BOLÍVAR, Simón. Manifesto de Cartagena (1812). In: Escritos políticos - Simão Bolívar. (Trad. Maria Clarinda Braz e Armando Silva Carvalho). Lisboa: Editoral Estampa, 1977. p. 57-70.

BOMFIM, Manoel. A América Latina - males de origem. 4. ed. Rio de Janeiro: Topbooks, 1993. 358 p.

FAUSTO, Bóris; DEVOTO, Fernando J. Brasil e Argentina — um ensaio de história comparada (1850-2002). São Paulo: Editora 34, 2004. 574 p.

FREDRIGO, Fabiana de Souza. As guerras de independência, as práticas sociais e o código de elite na América do século XIX - leituras da correspondência bolivariana. In: Varia Historia, Belo Horizonte, vol. 23, n. 38, p. 293-314, jul./dez. 2007.

LOLO, Eduardo. José Martí desde el exilio. Sección Estudios Culturales del Sitio Electrónico del Círculo de Cultura Panamericano, publicado en el año 2007. Disponível em: <http://www. circulodeculturapanamericano.org $>$ Acesso em: 27. jul. 2010.

LÓPEZ CHIRICO, Selva. América Latina na hora da independência. São Paulo: Secretaria de Estado da Educação, Fundação Memorial da América Latina, 2008. 112 p. il. (Coleção Fundadores da América Latina, v. 1).

LYNCH, John. As origens da independência da América Espanhola. In: BETHELL Leslie (Org.) História da América Latina: da Independência a 1870, v. III. Maria Clara Cescato (Trad.). São Paulo: Editora da Universidade de São Paulo; Imprensa Oficial do Estado; Brasília, DF — Fundação Alexandre de Gusmão, 2001. 1013 p.

MARTÍ, José. Nossa América. In: Nossa América. Antologia. Textos de José Martí selecionados por Roberto Fernández Retamar. Maria Angélica de Almeida Trajber (Trad.). São Paulo: HUCITEC; Associação Cultural José Martí, 1983. p. 194-201.

RETAMAR, Roberto Fernández. Introdução a José Martí. In: Nossa América. Antologia. Textos de José Martí selecionados por Roberto Fernández Retamar. Maria Angélica de Almeida Trajber (Trad.). São Paulo: HUCITEC; Associação Cultural José Martí, 1983. 254 p.

RODRIGUES, Miguel Urbano. Opções da revolução na América Latina. Rio de Janeiro: Paz e Terra, 1968. 222 p.

ROUSSEAU, 1762. Du Contrat Social. In: Jean-Jacques Rousseau. El Contrato Social. Discursos. 1. ed. Buenos Aires: Losada, 2008.

SOARES, Gabriela Pellegrino. Simón Bolívar. São Paulo: Secretaria de Estado da Educação, Fundação Memorial da América Latina, 2008. 112 p. il. (Coleção Fundadores da América Latina, v. 2).

SOCIANO, Graciela. Seleção de textos e introdução In: Escritos políticos - Simão Bolívar. Trad. Maria C. Braz e Armando S. Carvalho. Lisboa: Editoral Estampa, 1977. 212 p. 
SODRÉ, Nelson Werneck. O que se deve ler para conhecer o Brasil. 7. ed. Rio de Janeiro: Bertrand Brasil, 1997. 384 p.

VILLAÇA, Mariana Martins. José Martí. São Paulo: Secretaria de Estado da Educação, Fundação Memorial da América Latina, 2008. 88 p. il. (Coleção Fundadores da América Latina, v. 5).

\section{SITES:}

ALTMANN, Werner. O pensamento político e religioso de José Martí. 2003. 23 p. Disponível em: <http:// www.ihu.unisinos.br/uploads/publicacoes/edicoes/1162403435.74pdf.pdf> Acesso em: 26. jul. 2010.

BOLÍVAR, 1812. Manifesto de Cartagena, s/p. Disponível em: <http://www.analitica.com/bitblio/ bolivar/cartagena.asp> Acesso em: 15. jul. 2010.

1815. Carta de Jamaica, s/p. Disponível em: <http://www.simon-bolivar.org/Principal/ bolivar/cartadejamaica.html> Acesso em: 15. jul. 2010.

1819. Discursos de Angostura, s/p. Disponível em: <http://www.analitica.com/bitblio/ bolivar/angostura.asp> Acesso em: 18. jul. 2010.

.1825. Discurso perante el Congreso Constituyiente de Bolívia, s/p. Disponível em: $<$ http://www.analitica.com/bitblio/bolivar/bolivia.asp> Acesso em: 18. jul. 2010.

MARTÍ, 1884. El tercer año del Partido Revolucionário Cubano, s/p. Disponível em: <http:// www.josemarti.cu/files/El\%2otercer\%20ano\%20del\%2oPRC.pdf> Acesso em: 26. jul. 2010.

1891. Con todos y para el bien de todos, s/p. Disponível em: <http://www.josemarti.info/ documentos/con_todos.html> Acesso em: 26 jul. 2010.

1891. La Conferencia Monetaria de las Repúblicas de la América, S/P. Disponível em: $<\mathrm{http}: / /$ www.josemarti.info/documentos/conferencia_monetaria.html > Acesso em: 26. jul. 2010.

1891. Nuestra América, s/p. Disponível em: <http://www.josemarti.info/documentos/ nuestra_america.html> Acesso em: 26. jul. 2010.

1893. Mi Raza, s/p. Disponível em: <http://www.josemarti.info/documentos/ mi_raza.html> Acesso em: 26. jul. 2010.

. Madre América, 1889, s/p. Disponível em: <http://www.cubaminrex.cu/josemarti/ jmarti_madreamerica.htm> Acesso em: 26. jul. 2010.

. Maestros Ambulantes, 1884, s/p. Disponível em: <http://jose-marti.org/jose_marti/ obras/articulos/maestrosambulantes/maestrosambulantes1.htm> Acesso em: 26. jul. 2010. 